\title{
Efficacy, Safety, and Practicality of Tacrolimus Monitoring after Bone Marrow Transplant: Assessment of a Change in Practice
}

\author{
Jacky Cheung, Jason Wentzell, Melanie Trinacty, Pierre Giguère, Priya Patel, Natasha Kekre, \\ and Tiffany Nguyen
}

\begin{abstract}
Background: Currently, there is no standardized approach to the frequency of monitoring tacrolimus levels in patients who have undergone hematopoietic stem cell transplant (HSCT). Previously, the practice at the study hospital was to monitor tacrolimus levels daily throughout a patient's admission. A recent institutional study suggested that measurement of tacrolimus level is more frequent than needed to achieve consistent time in the therapeutic range (TTR), particularly after the first 7 days. As a result, tacrolimus monitoring was changed to daily measurement for the initial week of therapy, followed by measurements on Monday, Wednesday, and Friday in subsequent weeks.
\end{abstract}

Objective: To confirm the safety and efficacy of the recent practice change. Methods: This retrospective chart review of HSCT patients admitted to The Ottawa Hospital involved 68 patients in the pre-practice change group and 43 patients in the post-practice change group. Data on tacrolimus measurement were collected for up to 21 days after initiation of this medication. The proportion of TTR was compared between the 2 groups. Differences in the incidence and severity of renal dysfunction and the incidence of acute graft versus host disease (GVHD) were determined and described.

Results: In the pre-practice change cohort, the median proportion of TTR for tacrolimus was $40.5 \%$ for days $1-7,65.1 \%$ for days $8-14$, and $78.9 \%$ for days $15-21$, similar to the values for the post-practice change group (46.6\% [ $p=0.09], 62.9 \%[p=0.93]$, and $70.0 \%[p=0.22]$, respectively, for the same periods). The incidence of acute GVHD within 100 days after HSCT was $24 \%$ and $33 \%$ for the pre- and post-practice change cohorts, respectively. The incidence and severity of renal dysfunction were similar between the 2 groups.

Conclusion: The proportion of TTR for tacrolimus was not significantly affected by the recent practice change. Similarly, the incidence and severity of renal dysfunction and the incidence of acute GVHD did not appear to differ between the pre- and post-practice change groups.

Keywords: tacrolimus, acute graft-versus-host disease, time in therapeutic range, renal dysfunction, monitoring

\section{RÉSUMÉ}

Contexte : Il n'existe actuellement aucune approche standardisée portant sur la fréquence des contrôles des valeurs du tacrolimus pour les patients ayant subi une greffe de cellules souches hématopoïétiques (GCSH). Dans le passé, la pratique à l'hôpital où s'est déroulée l'étude consistait à les contrôler quotidiennement durant tout le séjour du patient. Une récente étude institutionnelle a laissé entendre que cette mesure était plus fréquente que nécessaire pour obtenir une marge thérapeutique régulière (TTR), particulièrement après les sept premiers jours. Par conséquent, une modification du contrôle des valeurs du tacrolimus préconise désormais des mesures quotidiennes pendant la première semaine de la thérapie, suivies de mesures le lundi, le mercredi et le vendredi au cours des semaines suivantes.

Objectif : Confirmer la sécurité et l'efficacité du récent changement apporté à la pratique.

Méthode : Cet examen rétrospectif des dossiers des patients GCSH admis à l'Hôpital d'Ottawa concernait 68 patients du groupe " avant le changement de pratique » et 43 du groupe " après le changement de pratique ". Les données relatives aux mesures des valeurs du tacrolimus ont été recueillies pendant les 21 premiers jours après le début de l'administration de ce médicament. La comparaison entre les deux groupes portait sur la proportion de TTR. Les différences d'incidence et de gravité du dysfonctionnement rénal et l'apparition de réaction aiguë du greffon contre l'hôte (GVHD) ont été définies et décrites.

Résultats : Dans la cohorte "avant le changement de pratique ", la proportion moyenne de TTR du tacrolimus était de $40,5 \%$ du $1^{\text {er }}$ au $7^{\text {e }}$ jour; de $65,1 \%$ du $8^{\mathrm{e}}$ au $14^{\mathrm{e}}$ jour et de $78,9 \%$ du $15^{\mathrm{e}}$ au $21^{\mathrm{e}}$ jour. Ces valeurs sont similaires à celles du groupe " après le changement de pratique » (respectivement 46,6\% [p=0,09], 62,9\% [p=0,93] et 70,0\% $[p=0,22]$ pendant les mêmes périodes). L'incidence de réaction aiguë du greffon contre l'hôte dans les 100 jours après la GCSH se montait respectivement à $24 \%$ et à $33 \%$ dans les cohortes " avant et après le changement de pratique ». L'incidence et la gravité du dysfonctionnement rénal étaient similaires dans les deux groupes.

Conclusion : La proportion de TTR relative au tacrolimus n'a pas été modifiée de manière significative par le changement récent de pratique. De même, l'incidence et la gravité du dysfonctionnement rénal et l'incidence de réaction aiguë du greffon contre l'hôte ne semblaient pas différer entre les groupes avant et après le changement de pratique.

Mots-clés : tacrolimus, réaction aiguë du greffon contre l'hôte, marge thérapeutique, dysfonctionnement rénal, contrôle 


\section{INTRODUCTION}

Cor various hematological malignancies, allogeneic bone - marrow transplant (also known as hematopoietic stem cell transplant [HSCT]) is a potentially curative treatment in which hematopoietic cells are retrieved from human leukocyte antigenmatched donors. ${ }^{1}$ Upon completion of a chemotherapy conditioning regimen, patients receive an infusion of matched cells. ${ }^{2} \mathrm{~A}$ potentially fatal complication of HSCT is graft-versus-host disease (GVHD), in which donor-derived immune cells, primarily $\mathrm{T}$ lymphocytes, trigger an immunological response against the recipient's tissues. ${ }^{3}$ The organs most often affected by GVHD are the skin, gastrointestinal tract, and liver. ${ }^{4}$ Although the success of HSCT has improved, $35 \%$ to $50 \%$ of post-transplant patients still experience GVHD, which illustrates the importance of GVHD prophylaxis after allogeneic HSCT to prevent further morbidity or mortality. ${ }^{5}$

Acute GVHD is the second leading cause of mortality among patients who have undergone allogeneic HSCT. ${ }^{6}$ Historically, GVHD that manifested within 100 days after HSCT was defined as acute, and GVHD that manifested 100 days or more after the transplant was termed chronic. ${ }^{7}$ Classic acute GVHD has a characteristic presentation of erythema, maculopapular rash, nausea, vomiting, profuse diarrhea, ileus, or cholestatic liver disease. $^{8}$

Tacrolimus is an immunosuppressant that has proven effective in preventing GVHD when used in combination with methotrexate. ${ }^{9}$ Tacrolimus inhibits T-lymphocyte activation by forming a complex with FK-binding protein 12, which blocks the serine-threonine phosphatase activity of calcineurin. ${ }^{9,10}$ This blockage in the serine-threonine phosphatase activity of calcineurin results in inhibition of the further downstream signal transduction that occurs with GVHD. ${ }^{10}$
It has been reported that about $25 \%$ to $50 \%$ of all patients undergoing bone marrow transplant experience acute kidney injury. ${ }^{11}$ GVHD, hepatic veno-occlusive disease, and high-dose radiation with fluid loss due to diarrhea and vomiting can cause renal failure. An adverse effect of tacrolimus is renal dysfunction, and this adverse effect may be caused by other drugs as well. ${ }^{11}$ The nephrotoxicity of calcineurin inhibitors, such as tacrolimus, is due to vasoconstriction of the afferent renal arterioles. More than half of patients who are taking tacrolimus will experience a doubling of their baseline serum creatinine. ${ }^{12}$ It appears that calcineurin inhibitors influence renal function in a dose-dependent manner. ${ }^{11}$ Management of acute kidney injury mainly involves supportive care, such as withdrawal of nephrotoxic drugs and dose reduction of calcineurin inhibitors. ${ }^{13}$

The standard of kinetic tacrolimus monitoring is the measurement of trough concentrations. ${ }^{14}$ The target trough level of tacrolimus, as reported in the literature, ranges from 5 to $20 \mu \mathrm{g} / \mathrm{L} .{ }^{14-16}$ Tacrolimus levels below $5 \mu \mathrm{g} / \mathrm{L}$ have increased the risk of GVHD, whereas levels above $20 \mu \mathrm{g} / \mathrm{L}$ have been associated with nephrotoxicity. ${ }^{15}$ Although the monitoring of tacrolimus levels in the blood is important to prevent complications, the optimal frequency of monitoring in patients who have undergone HSCT is currently unknown, because there is no standard guideline or recommendation for tacrolimus in the setting of HSCT. Furthermore, no target proportion of time in therapeutic range (TTR) has been reported in the literature. This lack of evidence is apparent from the lack of a standardized process for tacrolimus monitoring in HSCT patients across Canadian transplant centres (Table 1). Initial dosing of tacrolimus, route of administration, target levels, and frequency of monitoring all vary among institutions.

\section{Table 1. Use of Tacrolimus at Other Canadian Institutions}

\begin{tabular}{|c|c|c|c|c|}
\hline Institute (Location) & Tacrolimus Dosage & Target Level & $\begin{array}{c}\text { Frequency of } \\
\text { Monitoring }\end{array}$ & $\begin{array}{l}\text { Clinician Responsible } \\
\text { for Monitoring }\end{array}$ \\
\hline $\begin{array}{l}\text { Princess Margaret } \\
\text { Hospital (Toronto, Ontario) }\end{array}$ & $0.015 \mathrm{mg} / \mathrm{kg} \mathrm{IV} \mathrm{q12h}$ & $7-15 \mu \mathrm{g} / \mathrm{L}$ & Twice weekly & Pharmacist, physician \\
\hline $\begin{array}{l}\text { Hamilton Health Sciences } \\
\text { (Hamilton, Ontario) }\end{array}$ & $\begin{array}{l}1 \mathrm{mg} \text { over } 24 \mathrm{~h} \text { by } \\
\text { continuous IV infusion }\end{array}$ & $5-15 \mu g / L$ & $\begin{array}{l}\text { Daily for } 4 \text { or } 5 \text { days, } \\
\text { then } 3 \text { times weekly }\end{array}$ & $\begin{array}{l}\text { Pharmacist, physician, } \\
\text { nurse practitioner } \\
\text { (outpatient setting) }\end{array}$ \\
\hline $\begin{array}{l}\text { Cancer Care Manitoba } \\
\text { (Winnipeg, Manitoba) }\end{array}$ & $\begin{array}{l}0.03 \mathrm{mg} / \mathrm{kg} \text { over } 24 \mathrm{~h} \text { by } \\
\text { continuous IV infusion } \\
\text { (myeloablative), } 0.2 \mathrm{mg} / \mathrm{kg} \text { per day } \\
\text { PO divided q12h }\end{array}$ & $\begin{array}{l}\text { 8-12 } \mu \mathrm{g} / \mathrm{L} \text { initially, } \\
\text { then } 5-15 \mu \mathrm{g} / \mathrm{L} \text { at } \\
\text { day } 50 \text { post-transplant } \\
\text { and beyond }\end{array}$ & $\begin{array}{l}\text { Twice weekly for inpatients, } \\
\text { once weekly for outpatients }\end{array}$ & Pharmacist, physician \\
\hline $\begin{array}{l}\text { Baker Cancer Centre } \\
\text { (Calgary, Alberta) }\end{array}$ & $\begin{array}{l}0.12-0.15 \mathrm{mg} / \mathrm{kg} \text { per day PO } \\
\text { divided q12h or } 0.03 \mathrm{mg} / \mathrm{kg} \text { over } \\
24 \mathrm{~h} \text { by continuous IV infusion }\end{array}$ & $5-15 \mu g / L$ & $\begin{array}{l}\text { Three times weekly for } \\
\text { inpatients, once weekly } \\
\text { for outpatients }\end{array}$ & Pharmacist \\
\hline $\begin{array}{l}\text { Nova Scotia Health } \\
\text { Authority (Halifax, } \\
\text { Nova Scotia) }\end{array}$ & $\begin{array}{l}3 \text { mg PO bid } \\
\text { (non-myeloablative transplant) }\end{array}$ & $5-15 \mu g / L$ & Twice weekly & $\begin{array}{l}\text { Pharmacist, physician, } \\
\text { nurse practitioner } \\
\text { (outpatient) }\end{array}$ \\
\hline $\begin{array}{l}\text { Eastern Health } \\
\text { (St John's, Newfoundland) }\end{array}$ & $3 \mathrm{mg}$ PO bid & $5-15 \mu g / L$ & Twice weekly & $\begin{array}{l}\text { Nurse practitioner } \\
\text { (outpatient) }\end{array}$ \\
\hline $\begin{array}{l}\text { Vancouver Coastal Health } \\
\text { (Vancouver, British Columbia) }\end{array}$ & $\begin{array}{l}0.03 \mathrm{mg} / \mathrm{kg} \text { over } 24 \mathrm{~h} \text { by } \\
\text { continuous IV infusion }\end{array}$ & $5-10 \mu g / L$ & Twice weekly & Pharmacist \\
\hline
\end{tabular}


At The Ottawa Hospital, tacrolimus is used in combination with methotrexate for GVHD prophylaxis in patients undergoing HSCT. Tacrolimus is usually initiated 3 days before the transplant procedure (i.e., day -3). The immediate-release formulation of tacrolimus (Prograf) is given to all patients orally at a dose of $0.13 \mathrm{mg} / \mathrm{kg}$ per day, divided every $12 \mathrm{~h}$ and adjusted to maintain the target trough level between 5 and $10 \mu \mathrm{g} / \mathrm{L}$.

This study was based on a previous (unpublished) retrospective pilot study performed in 2016, when samples for measurement of tacrolimus levels were drawn daily at the study institution. That pilot study showed that dosing interventions were made frequently during the first 7 days of tacrolimus therapy, when levels are monitored daily. After the first 7 tacrolimus measurements, TTR and number of dosing interventions remained steady between the 8 th and 14th measurements and between the 15th and 21 st measurements, across a range of patient characteristics. That pilot study also described the initial dosing of tacrolimus, compared the proportion of TTR between the three 7-day intervals (over the total course of 21 measurements), and compared the proportion of TTR between different groups of patients (those who had inpatient versus outpatient procedures; those receiving versus not receiving interacting medications). It was shown that monitoring tacrolimus levels daily after day 7 of tacrolimus therapy did not significantly affect the proportion of TTR. Over the first 7 measurements, the mean proportion of TTR was 46\%; TTR increased to $64 \%$ over measurements 8 to 14 and increased further to $67 \%$ over measurements 15 to 21 . For all patients in the pilot study, tacrolimus level was measured daily for at least the first 14 days of therapy, after which, on the basis of clinician judgment and preference, monitoring frequency was reduced to 3 times weekly (Monday, Wednesday, and Friday) for $45 \%$ of patients; the remaining $55 \%$ of patients continued to undergo daily monitoring. Although the frequency of monitoring changed, the proportion of TTR stayed consistent. This observation was hypothesisgenerating and suggested that, at this institution, tacrolimus levels were measured more frequently than needed to achieve consistent TTR during inpatient care, particularly after the first 7 days. The pilot study found no difference in TTR for patients using interacting drugs, such as proton pump inhibitors and azole antifungals, which confirmed the practitioners' existing practice to empirically reduce tacrolimus dosage in conjunction with interacting medications. There was also no difference in tacrolimus TTR according to whether patients received their transplant as an inpatient or an outpatient.

The results of that pilot study led to a change, in August 2017, in tacrolimus monitoring practice within the Blood and Marrow Transplant program at The Ottawa Hospital. Previously, according to institutional recommendations, tacrolimus levels were measured daily for an indeterminate period during the hospital admission. The practice change involved drawing samples for measurement of tacrolimus levels daily for the first week of tacrolimus therapy and then on Monday, Wednesday, and Friday each week until hospital discharge or cessation of therapy. The current study was conducted to validate the recent practice change in tacrolimus monitoring and to ensure that measures of TTR, safety, and practicality were comparable between the pre- and post-practice change groups of patients.

The objectives of this retrospective study were as follows:

- to compare the median proportion of TTR for tacrolimus between a pre-practice change group and a post-practice change group of HSCT patients

- to describe the incidence of acute GVHD within 100 days after transplant in the pre-practice change group and the post-practice change group of HSCT patients receiving tacrolimus therapy

- to describe the incidence and severity of renal failure within 30 days after initiating tacrolimus therapy in the pre-practice change group and the post-practice change group of HSCT patients receiving tacrolimus therapy

- to describe the total number of samples drawn for tacrolimus measurement overall and per weekend day in the prepractice change group and the post-practice change group of HSCT patients receiving tacrolimus therapy

- to describe the number of protocol deviations that occurred during the study period

\section{METHODS}

A retrospective chart review was conducted to assess the change in standard of practice at The Ottawa Hospital. The pre-practice change group consisted of patients who underwent HSCT at this hospital between November 1, 2015, and October 31,2016 . The post-practice change comparator group consisted of patients who underwent HSCT at the same hospital between September 1, 2017, and February 28, 2018. The difference in study duration between the 2 groups was related to use of a convenience sample and the time constraints of a pharmacy residency year. Patients had to have received GVHD prophylaxis with oral tacrolimus for at least 21 days to be eligible for inclusion in the study. Those who had received their transplant at an institution other than The Ottawa Hospital were excluded.

Patients who had received oral tacrolimus for at least 21 days during the periods of interest were identified from pharmacy records. The patient list generated in this way was screened against the inclusion criteria described above to determine eligibility.

Data for serum tacrolimus levels were collected from electronic health records at The Ottawa Hospital. For each patient, the first level reported after the day of initiation of tacrolimus was collected. The day of initiation of tacrolimus therapy was defined relative to the day of transplant, with the day of transplant being denoted as "day 0". All tacrolimus levels reported between the day of initiation to 21 days after initiation were recorded. 
The proportion of TTR was defined as the proportion of time that a patient's tacrolimus levels were within the institutionally accepted therapeutic range of 5 to $10 \mu \mathrm{g} / \mathrm{L}$, relative to the total period studied for that patient. The proportion of TTR between 2 consecutive levels was extrapolated using a pharmacokinetic geometric model, with thresholds of 5 and $10 \mu \mathrm{g} / \mathrm{L}$.

The incidence of acute GVHD was assessed using the surrogate marker of systemic steroid initiation, corroborated by clinical notes describing suspected acute GVHD, as documented at the time of patient care.

Data for serum creatinine levels were collected for 30 days after initiation of tacrolimus therapy. The incidence and severity of renal dysfunction were assessed with the Kidney Disease: Improving Global Outcomes (KDIGO) acute kidney injury staging criteria (Table 2) and a comparison between baseline and peak serum creatinine levels. The serum creatinine level recorded on day 1 was considered as the baseline.

Protocol deviations were defined, within the post-practice change group, as measurements based on samples that were drawn on days other than Monday, Wednesday, or Friday, or measurements that were missed on those days during the study period.

An in-service education session was provided to nursing staff at the end of November 2017 (about 3 months after the change in monitoring frequency) to reinforce uptake of the practice change.

To compare the proportion of TTR between the 2 groups, a Mann-Whitney $U$ test was performed with SPSS software (version 20, IBM Corporation, Armonk, New York). For the other 4 research objectives, data were analyzed using descriptive statistics.

Table 2. Staging of Acute Kidney Injury*

\begin{tabular}{|c|c|c|}
\hline Stage & Serum Creatinine & Urine Output \\
\hline 1 & $\begin{array}{c}\text { 1.5-1.9 times baseline } \\
\text { OR } \\
\geq 0.3 \mathrm{mg} / \mathrm{dl}(\geq 26.5 \mu \mathrm{mol} / \mathrm{l}) \text { increase }\end{array}$ & $<0.5 \mathrm{ml} / \mathrm{kg} / \mathrm{h}$ for $6-12$ hours \\
\hline 2 & 2.0-2.9 times baseline & $<0.5 \mathrm{ml} / \mathrm{kg} / \mathrm{h}$ for $\geq 12$ hours \\
\hline 3 & $\begin{array}{c}\text { 3.0 times baseline } \\
\text { OR } \\
\text { Increase in serum creatinine } \\
\text { to } \geq 4.0 \mathrm{mg} / \mathrm{dl}(\geq 353.6 \mathrm{mmol} / \mathrm{l}) \\
\mathrm{OR} \\
\text { Initiation of renal replacement therapy } \\
\text { OR } \\
\text { In patients }<18 \text { years, decrease in } \\
\text { eGFR to }<35 \mathrm{ml} / \mathrm{min} \text { per } 1.73 \mathrm{~m}^{2}\end{array}$ & $\begin{array}{c}<0.3 \mathrm{ml} / \mathrm{kg} / \mathrm{h} \text { for } \geq 24 \text { hours } \\
\text { OR } \\
\text { Anuria for } \geq 12 \text { hours }\end{array}$ \\
\hline \multicolumn{3}{|c|}{$\begin{array}{l}\text { eGFR = estimated glomerular filtration rate. } \\
\text { *Reproduced, with permission, from Kidney Disease: Improving Global Outcome } \\
\text { (KDIGO) Acute Kidney Injury Work Group. KDIGO clinical practice guideline for } \\
\text { acute kidney injury. Kidney Int Suppl. 2012;2(1):1-138. }\end{array}$} \\
\hline
\end{tabular}

Table 3. Patient Characteristics

\begin{tabular}{lrrrr} 
& \multicolumn{3}{c}{ Timing; No. (\%) of Patients* } \\
\cline { 2 - 5 } Characteristic & $\begin{array}{c}\text { Before Practice } \\
\text { Change }(\boldsymbol{n}=\mathbf{6 8})\end{array}$ & $\begin{array}{c}\text { After Practice } \\
\text { Change }(\boldsymbol{n}=\mathbf{4 3})\end{array}$ \\
\hline Age (years) (mean and range) & 50 & $(18-70)$ & 51 & $(18-73)$ \\
Age $\geq 65$ years & 5 & $(7)$ & 10 & $(23)$ \\
\hline Sex, male & 43 & $(63)$ & 28 & $(65)$ \\
\hline Serum creatinine $(\mu \mathrm{mol} / \mathrm{L})$ & 61 & $(31-113)$ & $62(39-104)$ \\
(mean and range) & & & & \\
\hline Indication for HSCT & 30 & $(44)$ & 25 & $(58)$ \\
Acute leukemia† & 6 & $(9)$ & 5 & $(12)$ \\
Chronic leukemiał & 10 & $(15)$ & 6 & $(14)$ \\
Myelodysplastic syndrome & 11 & $(16)$ & 4 & $(9)$ \\
Non-Hodgkin lymphoma & 5 & $(7)$ & 0 & $(0)$ \\
Aplastic anemia & 4 & $(6)$ & 0 & $(0)$ \\
Multiple myeloma & 2 & $(3)$ & 2 & $(5)$ \\
Myelofibrosis & 0 & $(0)$ & 1 & $(2)$ \\
Krabbe disease & & & & \\
\hline
\end{tabular}

HSCT = hematopoietic stem cell transplant.

*Except where indicated otherwise.

tAcute myeloid leukemia, acute lymphoblastic leukemia.

¥Chronic myelogenous leukemia, chronic myelomonocytic leukemia,

chronic lymphocytic leukemia, hairy cell leukemia, prolymphocytic leukemia. 


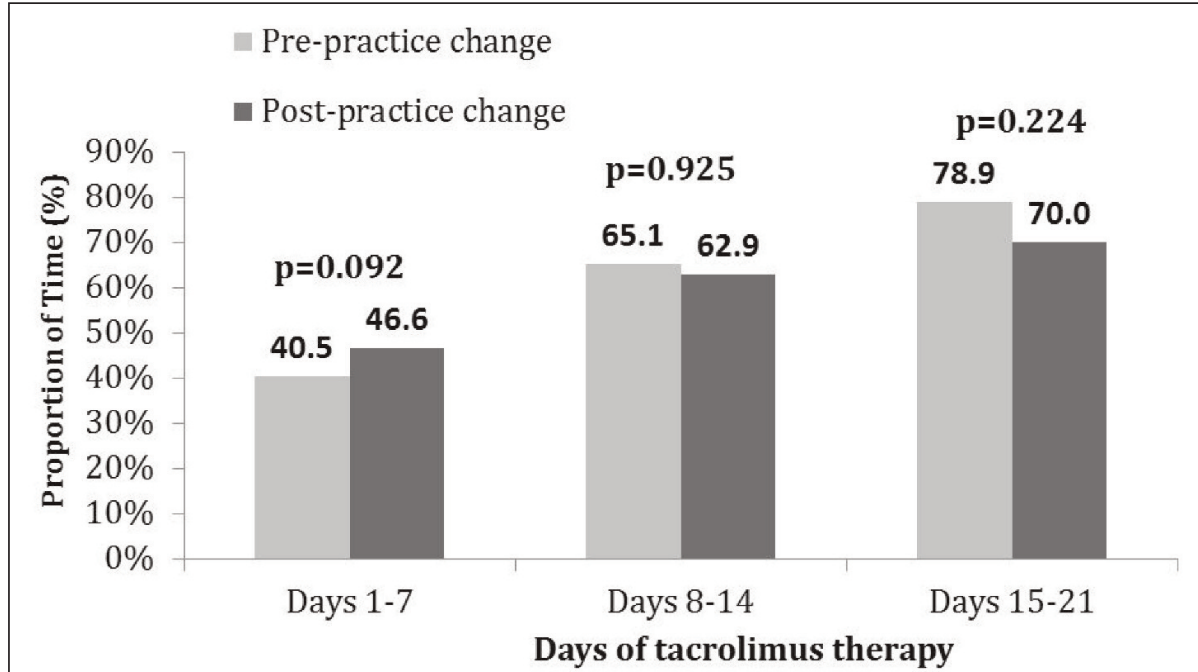

Figure 1. Median proportion of time with tacrolimus within therapeutic range.

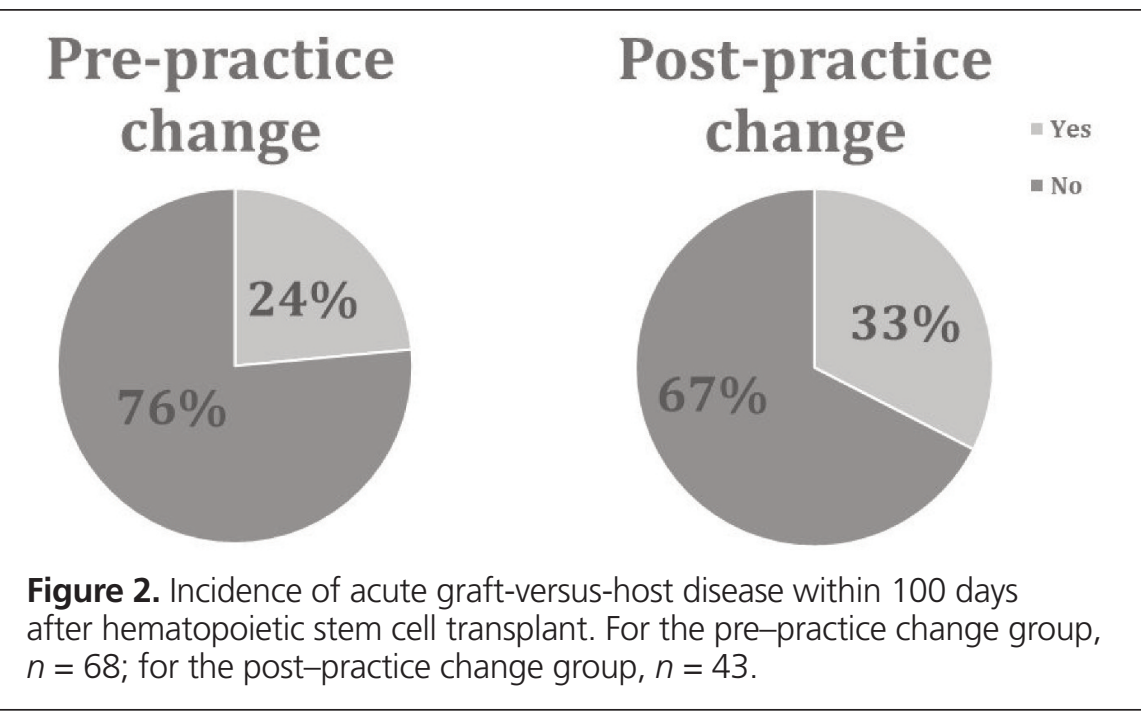

\section{RESULTS}

The pre-practice change group had a total of 68 patients, and the post-practice change group had a total of 43 patients. The mean age, proportions of men and women, and baseline serum creatinine were similar between the 2 groups (Table 3 ), but the proportion of patients older than 65 years was higher in the post-practice change group. The indications for HSCT were similar between the 2 groups. The initial dose of tacrolimus varied among patients because the starting dose for this drug is weightbased.

The median proportion of TTR did not differ between groups in the first 7 days of tacrolimus therapy: $40.5 \%$ in the pre-practice change group and $46.6 \%$ in the post-practice change group ( $p=0.09$ ) (Figure 1). Similarly, there was no difference between the groups in median proportion of TTR for days
$8-14(65.1 \%$ versus $62.9 \%, p=0.93)$ and days $15-21(78.9 \%$ versus $70.0 \%, p=0.22$ ).

The incidence of acute GVHD within 100 days after HSCT was $24 \%(16 / 68)$ in the pre-practice change group and 33\% $(14 / 43)$ in the post-practice change group (Figure 2).

The incidence of all-stage renal dysfunction within 30 days after HSCT was 65\% in the pre-practice change group and 70\% in the post-practice change group (Table 4). In the pre-practice change group, $38 \%$ of patients had stage 1 renal dysfunction, $16 \%$ had stage 2 renal dysfunction, and $10 \%$ had stage 3 renal dysfunction. In the post-practice change group, $42 \%, 16 \%$, and $12 \%$ of patients had stage 1 , stage 2 , and stage 3 renal dysfunction, respectively.

In total, 1280 and 584 samples were drawn for measurement of tacrolimus during the study period for the pre-and postpractice change groups, respectively, for an average of 19 and 
14 samples per patient, respectively (Table 5). Of these samples, 347 and 100 were drawn on weekends for the pre-and postpractice change groups, for an average of 0.85 and 0.39 samples per weekend day, respectively (Table 5).

Overall, there were a total of 99 protocol deviations after the practice change, for an average of 2.3 deviations per patient (Table 6). Of these 99 protocol deviations, 65 occurred before and 34 after delivery of the in-service nursing education session (Table 6), for an average of 3.1 protocol deviations per patient before and 1.5 protocol deviations per patient after the nursing education session (Table 6). Protocol deviations included both missed measurements (i.e., missed on Monday, Wednesday, or Friday or at any point during the first 7 days of therapy) and extra measurements (i.e., on a day other than Monday, Wednesday, or Friday).

\section{DISCUSSION}

This study aimed to assess efficacy and safety outcomes, including proportion of TTR for tacrolimus, incidence of acute GVHD, and incidence and severity of renal dysfunction in patients who have undergone allogeneic HSCT, after a change in the standard of practice for tacrolimus monitoring at the study institution. There is currently a lack of evidence about optimal monitoring frequency of tacrolimus levels, and there is no standardized approach across all Canadian transplant centres. To our knowledge, this is the first study comparing different frequencies of tacrolimus monitoring in the setting of allogeneic HSCT.

In this study, we used proportion of TTR as a marker to assess how well tacrolimus levels were maintained during therapy. Use of proportion of TTR as a marker for tacrolimus effectiveness has been employed in other studies. ${ }^{17,18}$ Because the data for this variable did not show a normal distribution, we reported median values. Although there were small differences in the proportion of TTR between the 2 study groups, they were not statistically or clinically significant. The results suggest that switching the monitoring frequency of tacrolimus from once daily for the entire hospital stay to once daily for the first 7 days of therapy and then 3 times weekly did not affect the overall proportion of TTR. In addition, some centres monitor tacrolimus less frequently than daily for the first 7 days (Table 1).

In 2 previous studies, the blood levels of tacrolimus significantly affected development of grades II to IV acute GVHD. ${ }^{19,20}$ However, those studies also found differing ranges of tacrolimus blood levels between patients with grade 0 or I acute GVHD

Table 4. Incidence of Renal Dysfunction with 30 days after Hematopoietic Stem Cell Transplant

\begin{tabular}{lcc}
\multirow{2}{*}{$\begin{array}{l}\text { Stage of } \\
\text { Renal Dysfunction }\end{array}$} & \multicolumn{2}{c}{ Timing; No. of Patients } \\
\cline { 2 - 3 } & $\begin{array}{c}\text { Before Practice } \\
\text { Change }(\boldsymbol{n}=\mathbf{6 8})\end{array}$ & $\begin{array}{c}\text { After Practice } \\
\text { Change }(\boldsymbol{n}=\mathbf{4 3})\end{array}$ \\
\hline All stages & $44(65)$ & $30(70)$ \\
1 & $26(38)$ & $18(42)$ \\
2 & $11(16)$ & $7(16)$ \\
3 & $7(10)$ & $5(12)$ \\
\hline
\end{tabular}

Table 5. Samples Drawn for Measurement of Tacrolimus Level

\begin{tabular}{lcc} 
Variable & $\begin{array}{c}\text { Before Practice } \\
\text { Change }(\boldsymbol{n}=\mathbf{6 8})\end{array}$ & $\begin{array}{c}\text { After Practice } \\
\text { Change }(\boldsymbol{n}=\mathbf{4 3})\end{array}$ \\
\hline Total no. of samples drawn & 1280 & 584 \\
Mean no. of samples per patient & 19 & 14 \\
Total no. of samples drawn & 347 & 100 \\
on weekends & & \\
No. of weekend days & 408 & 258 \\
No. of weekend samples & 0.85 & 0.39 \\
per weekend day & & \\
\hline
\end{tabular}

Table 6. Protocol Deviations after Practice Change

\begin{tabular}{lcc} 
Timeframe & $\begin{array}{c}\text { Total No. of } \\
\text { Deviations }\end{array}$ & $\begin{array}{c}\text { Mean No. of } \\
\text { Deviations per Patient }\end{array}$ \\
\hline $\begin{array}{l}\text { Overall study period } \\
(n=43 \text { patients) }\end{array}$ & 99 & 2.3 \\
$\begin{array}{l}\text { Before nursing education } \\
(n=21 \text { patients) }\end{array}$ & 65 & 3.1 \\
$\begin{array}{l}\text { After nursing education } \\
(n=22 \text { patients) }\end{array}$ & 34 & 1.5 \\
\hline
\end{tabular}


and those with grade II to IV acute GVHD (> $7 \mathrm{ng} / \mathrm{mL}$ and $10-20 \mathrm{ng} / \mathrm{mL}$, respectively). ${ }^{19,20}$ Gao and others ${ }^{21}$ found that the incidence of acute GVHD in haploidentical HSCT patients, with tacrolimus levels between 10 and $15 \mu \mathrm{g} / \mathrm{L}$, was $29.1 \%$. Watanabe and others ${ }^{19}$ reported a $34.8 \%$ incidence of acute GVHD in pediatric patients who had undergone allogeneic HSCT and were receiving tacrolimus, with tacrolimus levels of at least $7 \mu \mathrm{g} / \mathrm{L}$. Nash and others 9 showed a $56 \%$ probability of acute GVHD based on a Kaplan-Meier estimate, which is higher than the incidence reported in the other studies mentioned. Overall, these incidence values for acute GVHD are consistent with our study results. Our study did not aim to statistically analyze the difference in incidence of acute GVHD because the study population was small. Continued monitoring for acute GVHD in the postpractice change group may be warranted for future studies.

With regard to kidney dysfunction, we found similar incidence and severity between the pre- and post-practice change groups, which suggests that the change in tacrolimus monitoring practice did not affect renal function. However, this study used only peak serum creatinine values to assess renal dysfunction. We did not consider urine output, which is also included in the KDIGO staging criteria, ${ }^{22}$ because patients were being monitored as outpatients and urine output could not be tracked. This study described but did not analyze the difference in incidence and severity of renal dysfunction between the 2 study groups. Continued monitoring for renal dysfunction in the post-practice change group should be explored in future studies.

Partway through the study period, we delivered an in-service nursing education session to justify, promote, and remind staff in the Blood and Marrow Transplant program about the recent practice change at our institution, The intent of this education session was to prevent or reduce potential protocol deviations. Although protocol deviations occurred even after nursing education, they could be attributed to the fact that patients were sometimes given "days off" from follow-up if the physician deemed their condition to be stable. When patients missed a tacrolimus measurement on an intended day, a sample was sometimes drawn on another day, outside of the defined protocol.

Overall in this study, the average number of tacrolimus measurements per patient decreased from 19 before to 14 after implementation of the practice change. In practical terms, this resulted in fewer early morning follow-up visits for patients, fewer blood samples being sent to the laboratory for analysis, and a reduced workload for nurses and pharmacists. There was also a decrease in the number of measurements per weekend day, from 0.85 to 0.39 , after the practice change. Fewer weekend measurements would help to improve weekend nursing and pharmacy workloads, at a time when fewer staff are scheduled. In addition, based on an average cost of $\$ 15$ per tacrolimus measurement and an average of 100 HSCT patients per year at the study institution, the overall reduction in tacrolimus measurements would equate to about $\$ 7500$ of direct savings per year.
This study had several limitations. The surrogate marker of systemic steroid initiation that was used to determine the incidence of acute GVHD would have excluded less severe cases treated only with topical corticosteroids and thus might have led to underestimation of the true incidence of acute GVHD. In addition, as stated previously, the small sample size limited our ability to compare differences in acute GVHD incidence. Because of the retrospective study design, the indications for transplant were not balanced between the groups, and patients with different indications would receive different conditioning regimens. However, this study realistically reflects the blood and marrow transplant practice setting. Another limitation was use of the surrogate marker of peak serum creatinine to determine renal dysfunction. Use of this marker might have overestimated the true incidence and severity of renal dysfunction, because factors such as dehydration and concomitant nephrotoxic therapy might have caused a transient spike in serum creatinine, and the patterns of serum creatinine change would not have been taken into account. Finally, the 2 study groups had differing sample sizes, because the time constraints for a pharmacy resident project dictated use of a convenience sample. More specifically, the inclusion period was shorter for the post-practice change group than for the prepractice change group, which likely explains the lower number of patients during the post-practice change period. However, the results appeared consistent between the 2 groups, despite the lower denominator, and we do not believe the difference in the number of patients between the 2 groups would have significantly affected the results.

\section{CONCLUSION}

This study showed that monitoring tacrolimus levels daily for the first 7 days of therapy and then each Monday, Wednesday, and Friday thereafter did not result in a significant change in the proportion of TTR; as a result, it can be considered a clinically appropriate practice. This practice change did not seem to affect the incidence of acute GVHD or the incidence and severity of renal dysfunction. However, it has promoted patient convenience, has improved workloads of the transplant team and of pharmacists, and has yielded direct cost savings through a reduction in the frequency of sampling for tacrolimus measurements. Further studies with larger sample sizes and evaluation of the severity of acute GVHD in each patient would further validate these results.

\section{References}

1. Kanakry CG, Fuchs EJ, Luznik L. Modern approaches to HLA-haploidentical blood or marrow transplantation. Nat Rev Clin Oncol. 2016;13(1):10-24

2. Little MT, Storb R. History of haematopoietic stem-cell transplantation. Nat Rev Cancer. 2002;2(3):231-8.

3. Perkey E, Maillard I. New insights into graft-versus-host disease and graft rejection. Annu Rev Pathol. 2018;13:219-45.

4. Ratanatharathorn V, Nash RA, Przepiorka D, Devine SM, Klein JL, Weisdorf $\mathrm{D}$, et al. Phase III study comparing methotrexate and tacrolimus (prograf, FK506) with methotrexate and cyclosporine for graft-versus-host disease prophylaxis after HLA-identical sibling bone marrow transplantation. Blood. 1998;92(7):2303-14 
This single copy is for your personal, non-commercial use only.

For permission to reprint multiple copies or to order presentation-ready copies for distribution, contact CJHP at publications@cshp.ca

5. Jacobsohn DA, Vogelsang GB. Acute graft versus host disease. Orphanet J Rare Dis. 2007;2:35

6. Nassereddine S, Rafei H, Elbahesh E, Tabbara I. Acute graft versus host disease: a comprehensive review. Anticancer Res. 2017;37(4):1547-55.

7. Toubai T, Sun Y, Reddy P. GVHD pathophysiology: is acute different from chronic? Best Prac Res Clin Haematol. 2008;21(2):101-17.

8. Jagasia M, Greinix H, Arora M, Williams KM, Wolff D, Cowen EW, et al. National Institutes of Health consensus development project on criteria for clinical trials in chronic graft-versus-host disease: I. The 2014 Diagnosis and Staging Working Group Report. Biol Blood Marrow Transplant. 2015;21(3): 389-401.e1.

9. Nash RA, Antin JH, Karanes C, Fay JW, Avalos BR, Yeager AM, et al. Phase 3 study comparing methotrexate and tacrolimus with methotrexate and cyclosporine for prophylaxis of acute graft-versus-host disease after marrow transplantation from unrelated donors. Blood. 2000;96(6):2062-8.

10. Christians U, Jacobsen W, Benet L, Lampen A. Mechanisms of clinically relevant drug interactions associated with tacrolimus. Clin Pharmacokinet. 2002;41(11):813-51.

11. Kemmner S, Verbeek M, Heemann U. Renal dysfunction following bone marrow transplantation. J Nephrol. 2017;30(2):201-9.

12. Woo M, Przepiorka D, Ippoliti C, Warkentin D, Khouri I, Fritsche H, et al Toxicities of tacrolimus and cyclosporin A after allogeneic blood stem cell transplantation. Bone Marrow Transplant. 1997;20(12):1095-8.

13. Hingorani S. Renal complications of hematopoietic-cell transplantation. NEngl J Med. 2016;374(23):2256-67.

14. Holt D, Armstrong VW, Griesmacher A, Morris RG, Napoli KL, Shaw LN. International Federation of Clinical Chemistry/International Association of Therapeutic Drug Monitoring and Clinical Toxicology working group on immunosuppressive drug monitoring. Ther Drug Monit. 2002;24(1):59-67.

15. Przepiorka D, Nash R, Wingard J, Zhu J, Maher R, Fitzsimmons W, et al. Relationship of tacrolimus whole blood levels to efficacy and safety outcomes after unrelated donor marrow transplantation. Biol Blood Marrow Transplant. 1999;5(2):94-7.

16. Ganetsky A, Shah A, Miano T, Hwang W, He J, Loren A, et al. Higher tacrolimus concentrations early after transplant reduce the risk of acute GvHD in reduced-intensity allogeneic stem cell transplantation. Bone Marrow Transplant. 2015;51(4):568-72.

17. Ensor CR, Iasella CJ, Harrigan KM, Morrell MR, Moore CA, Shigemura $\mathrm{N}$, et al. Increasing tacrolimus time-in-therapeutic range is associated with superior one-year outcomes in lung transplant recipients. Am J Transplant. 2018;18(6):1527-33.

18. Davis S, Gralla J, Klem P, Tong S, Wedermyer G, Freed B, et al. Lower tacrolimus exposure and time in therapeutic range increase the risk of de novo donor-specific antibodies in the first year of kidney transplantation. Am J Transplant. 2017;18(4):907-15.

19. Watanabe N, Matsumoto K, Muramatsu H, Horibe K, Matsuyama T, Kojima S, et al. Relationship between tacrolimus blood concentrations and clinical outcome during the first 4 weeks after SCT in children. Bone Marrow Transplant. 2010;45(7):1161-6.

20. Mori T, Kato J, Shimizu T, Aisa Y, Nakazato T, Yamane A, et al. Effect of early posttansplantation tacrolimus concentration on the development of acute graft-versus-host disease after allogeneic hematopoietic stem cell transplantation from unrelated donors. Biol Blood Marrow Transplant 2012;18(2):229-34
21. Gao L, Liu J, Zhang Y, Chen X, Gao L, Zhang C, et al. Low incidence of acute graft-versus-host disease with short term tacrolimus in haploidentical hematopoietic stem cell transplantation. Leuk Res. 2017;57:27-36.

22. Kidney Disease: Improving Global Outcomes (KDIGO) Acute Kidney Injury Work Group. KDIGO clinical practice guideline for acute kidney injury. Kidney Int Suppl. 2012;2 Suppl 1:1-138.

Jacky Cheung, BSC, PharmD, ACPR, was, at the time of this study, a Pharmacy Resident with the Pharmacy Department of The Ottawa Hospital, Ottawa, Ontario. He is now a Clinical Pharmacist with The Ottawa Hospital.

Jason Wentzell, BSCPharm, ACPR, BCOP, is a Clinical Pharmacist with the Pharmacy Department of The Ottawa Hospital, Ottawa, Ontario.

Melanie Trinacty, BSc, BScPharm, ACPR, is a Clinical Pharmacist with the Pharmacy Department of The Ottawa Hospital, Ottawa, Ontario.

Pierre Giguère, BPharm, MSc, is a Clinical Pharmacist with the Pharmacy Department of The Ottawa Hospital, Ottawa, Ontario.

Priya Patel, BSC, PharmD, ACPR, is a Clinical Pharmacist with the Pharmacy Department of the Princess Margaret Cancer Centre, Toronto Ontario.

Natasha Kekre, BSC, MD, MPH, FRCPC, is a Staff Hematologist with the Blood and Marrow Transplant Program, The Ottawa Hospital, Ottawa, Ontario.

Tiffany Nguyen, BScPharm, ACPR, BCOP, is a Clinical Pharmacist with the Pharmacy Department of The Ottawa Hospital, Ottawa, Ontario.

Competing interests: Jason Wentzell has received an unrestricted research grant from Apobiologix for work unrelated to the study reported here. No other competing interests were declared.

\section{Address correspondence to:}

Dr Jacky Cheung

Pharmacy Department

The Ottawa Hospital General Campus

501 Smyth Road

Ottawa ON K1H 8 L6

e-mail: jacheung@toh.ca

Funding: None received 